\title{
FAKTOR - FAKTOR YANG MEMPENGARUHI MINAT PERILAKU WAJIB PAJAK ORANG PRIBADI DALAM MENGGUNAKAN E-FILING DI TANGERANG SELATAN
}

\author{
JOSHUA \\ RIAN SUMARTA \\ Sekolah Tinggi IImu Ekonomi Trisakti, Jl. Kyai Tapa No. 20, Jakarta, Indonesia \\ Joshuajojo27@gmail.com, rian_sumarta@yahoo.com
}

\begin{abstract}
The purpose of this research is to examine the influence of knowledge, perceptions of usability, perceived of ease, security and confidentiality, experience, readiness of information technology, complexity, to the interest in the behavior of individual taxpayers in using of e-filing. This study uses primary data collected through distributing questionnaires to each individual taxpayer in the South Tangerang region. The number of samples used in this study were 110 respondents. Sampling method that used in this study is accidental sampling method. The methods that used for data analysis are reliability testing, validity test, classical assumption test, coefficient of determination test, coefficient of correlation test, simultaneous regression test $(F)$, partial t-test. This study found that the perceptions of usability doesn't affect the interest of individual taxpayers' behavior in using e-filing, while knowledge, perceived of ease, security and secrecy, experience, readiness of information technology, and complexity affect taxpayer behavior interest in using e-filing.
\end{abstract}

Keywords: Knowledge, perceived ease, perceived usefulness, complexity, and e-filing

Abstrak: Tujuan dari penelitian ini adalah untuk meneliti pengaruh pengetahuan, persepsi kegunaan, persepsi kemudahan, keamanan dan kerahasiaan, pengalaman, kesiapan teknologi informasi, kompleksitas terhadap minat perilaku wajib pajak orang pribadi dalam menggunakan e-filing. Penelitian ini menggunakan data primer yang dikumpulkan melalui penyebaran kuesioner kepada setiap wajib pajak orang pribadi yang berada di wilayah Tangerang Selatan. Jumlah sampel yang digunakan dalam penelitian ini adalah 110 responden. Metode Pengambilan sampel yang dilakukan adalah metode accidental sampling. Metode yang digunakan untuk analisis data yaitu, uji reliabilitas, uji validitas, uji asumsi klasik, uji koefisien determinasi, uji koefisien korelasi, uji F, dan uji t. Berdasarkan hasil penelitian diketahui bahwa persepsi kegunaan tidak memiliki pengaruh terhadap minat perilaku wajib pajak orang pribadi dalam menggunakan e-filing, sementara variabel pengetahuan, persepsi kemudahan, keamanan dan kerahasiaan, pengalaman, kesiapan teknologi informasi, dan kompleksitas berpengaruh terhadap minat perilaku wajib pajak dalam menggunakan e-filing.

Kata kunci: Pengetahuan, persepsi kemudahan, persepsi kegunaan, dan e-filing

\section{PENDAHULUAN}

Pemerintah paham betul akan pentingnya peran pajak sebagai sumber utama pendapatan negara sehingga pemerintah selalu berupaya untuk dapat meningkatkan jumlah penerimaan dari sektor pajak di setiap tahunnya. Guna mencapai hal tersebut, berbagai strategi 
pun dilakukan pemerintah melalui Direktorat Jenderal Pajak dengan melaksanakan intensifikasi pajak yaitu penyempurnaan tata cara administrasi perpajakan. Penyempurnaan terhadap administrasi pajak dapat dilakukan dengan menerapkan modernisasi administrasi perpajakan berbasis sistem teknologi dan informasi. Salah satu pembaharuan sistem administrasi perpajakan di Indonesia adalah eFiling atau Electronic Filing System.

Saat ini, penyampaian SPT sudah dapat dilakukan secara online melalui fasilitas e-Filing. Penggunaan e-Filling bukanlah suatu keharusan bagi para wajib pajak, karena berdasarkan UU KUP, untuk tata cara penyampaian SPT wajib pajak juga masih dapat melaporkan SPT dengan cara datang secara langsung ke kantor pajak ataupun dengan cara melalui pengiriman dengan pos. Karena penyampaian SPT masih bersifat opsional bagi wajib pajak dan dapat memungkinkan untuk timbulnya suatu penelitian tentang hal - hal apa saja yang dapat menarik minat wajib pajak dalam menggunakan e-Filing dibandingkan dengan melaporkan SPT dengan cara datang langsung ke kantor pajak terdaftar.

$$
\text { Penelitian ini merupakan }
$$
pengembangan dari penelitian sebelumnya yang dilakukan oleh Rahayu (2016) dengan judul Faktor - Faktor yang Mempengaruhi Minat Perilaku Wajib Pajak Dalam Menggunakan EFiling Sebagai Sarana Pelaporan Pajak (Studi Empiris Wajib Pajak Orang Pribadi di Kediri). Dalam penelitian tersebut menggunakan variabel dependen minat perilaku wajib pajak dalam menggunakan e-Filing sedangkan variabel independen menggunakan pengetahuan, persepsi kegunaan, persepsi kemudahan, keamanan dan kerahasiaan, dan pengalaman. Penelitian tersebut menggunakan wajib pajak yang terdaftar di Kediri.

Penelitian ini memiliki perbedaan dengan penelitian Rahayu (2016), perbedaannya itu adalah dengan menambah variabel independen lainnya untuk menentukan faktor-faktor yang mempengaruhi minat perilaku wajib pajak dalam menggunakan e-Filing. Variabel independen yang digunakan adalah kesiapan teknologi informasi (Utami, 2017) dan kompleksitas (Ermawati dan Kuncoro, 2016). Berdasarkan uraian-uraian di atas, maka dalam penelitian ini mengambil judul "Faktor - Faktor yang Mempengaruhi Minat Perilaku Wajib Pajak Orang Pribadi Dalam Menggunakan e-Filing di Tangerang Selatan"

Adapun tujuan dari penelitian ini adalah untuk mengetahui faktor-faktor yang berpengaruh terhadap minat perilaku wajib pajak orang pribadi yang terdaftar pada Kantor Pelayanan Pajak wilayah Tangerang Selatan dalam menggunakan e-filing.

\section{Theory of Reasoned Action (TRA)}

Theory of Reasoned Action (TRA) dikemukakan oleh Martin Fishbein dan Ajzen pada tahun 1975. Asumsi dasar yang disusun dalam teori TRA ini adalah bahwa manusia berperilaku dengan cara atau tindakan yang sadar dan mempertimbangkan segala informasi yang telah tersedia atau diketahui sebelumnya oleh manusia tersebut. Theory of Reasoned Action ini dilakukan atau tidaknya ditentukan oleh niat seseorang. Ajzen mengatakan bahwa niat seseorang untuk melakukan atau tidak melakukan suatu perilaku tertentu dipengaruhi oleh dua faktor dasar.

Faktor pertama, berkaitan dengan sikap (attitude towards behavior) dan faktor kedua, berhubungan dengan pengaruh sosial yaitu norma subjektif (subjective norms). Kedua penentu dasar tersebut akan membentuk suatu kepercayaan (beliefs) bahwa mereka ingin melakukan suatu tindakan karena apabila mereka melakukan tindakan maka mereka percaya tindakan tersebut membawa keuntungan bagi mereka. Penelitian ini menggunakan TRA sebagai landasan untuk berasumsi mengenai bagaimana seseorang mempertimbangkan segala informasi yang telah diterima untuk membentuk suatu minat atau ketertarikan terhadap sesuatu hal. Berhubungan 
dengan e-Filing, ketertarikan wajib pajak untuk menggunakan e-Filing ditentukan oleh minat yang dibentuk dari sikap dan norma subjektif yang dimiliki wajib pajak. Sikap yang dapat membentuk minat dapat muncul dari bagaimana suatu wajib pajak berperilaku, yang dimaksud adalah perilaku wajib pajak yang telah bertahuntahun terbiasa dalam menggunakan teknologi. Perilaku pengguna yang sudah memiliki kebiasaan tersebut dapat mendorong minat pengguna untuk menggunakan e-Filing dan dapat memudahkan pengguna dalam beradaptasi menggunakan e-Filing. Setelah mempertimbangkan sikap tersebut akan muncul norma-norma subjektif yang berasal dari kepercayaan wajib pajak akan manfaat yang diberikan e-Filing lebih menguntungkan daripada cara pelaporan pajak dengan manual atau sistem yang lama. Sikap pada penelitian ini diartikan sebagai sikap yang biasa dilakukan pengguna berdasarkan pengalaman yang ia punya. Teori TRA dalam hal ini digunakan sebagai dasar pemikiran dari variabel pengalaman.

\section{Theory of Acceptence Model (TAM)}

Teori ini pertama kali dicetuskan oleh Davis dan Bagozzi pada tahun 1986. Davis, Bagozzi dan Warshaw (1989) mengusulkan TAM ini untuk menjelaskan individu menerima atau menolak untuk menggunakan teknologi informasi. Model TAM berasumsi bahwa seseorang mengadopsi suatu teknologi pada umumnya ditentukan oleh proses kognitif dan bertujuan untuk memuaskan pemakainya atau memaksimalkan kegunaan teknologi itu sendiri (Wibowo et al. 2009). Teori ini menjelaskan bagaimana faktor eksternal dapat mempengaruhi sikap, niat dan kepercayaan individu. Menurut TAM, penggunaan teknologi dapat dipengaruhi secara langsung maupun tidak langsung oleh niat pengguna, perilaku pengguna, persepsi pengguna akan manfaat yang diberikan oleh sistem teknologi dan persepsinya tentang kemudahan yang akan diberikan dari sistem baru tersebut. Tujuan dari
TAM adalah untuk menjelaskan faktor-faktor penentu dari penerimaan teknologi berbasis sistem informasi oleh pengguna dan menjelaskan perilaku dari pengguna teknologi informasi dengan variasi yang luas.

Teori model penerimaan (TAM) ini dapat digunakan untuk mengidentifikasi mengapa suatu sistem dapat diterima atau tidak diterima oleh individu. Model TAM menunjukkan bahwa ketika pengguna diberikan sebuah teknologi yang baru, maka akan timbul sejumlah faktor-faktor yang dapat mempengaruhi keputusan mereka tentang bagaimana dan kapan mereka akan menggunakan teknologi baru tersebut. Model TAM ini memiliki dua faktor utama dalam menilai penerimaan suatu teknologi yaitu Perceived Usefulness dan Perceived Ease of Use. Faktor Perceived Usefulness pada penelitian ini digunakan untuk melandasi variabel keamanan dan kerahasiaan serta kesiapan teknologi informasi. Keamanan dan kerahasiaan disini diartikan bagaimana wajib pajak memiliki suatu persepsi bahwa sistem e-Filing mampu menjaga keamanan dan kerahasiaan data yang dimiliki wajib pajak saat mereka melakukan input ke dalam sistem, dengan adanya persepsi tersebut akan memunculkan persepsi kegunaan dari sistem eFiling itu sendiri.

Variabel kesiapan teknologi informasi diartikan bahwa sejauh mana wajib pajak siap untuk siap menerima teknologi baru yakni eFiling selain itu, e-Filing juga harus memiliki kesiapan untuk mendukung kesiapan dari wajib pajak supaya pelaporan pajak dapat berjalannya dengan baik sesuai dengan harapan berbagai pihak. Hal ini dapat dikaitkan dengan faktor utama pada teori TAM yakni Perceived Usefulness atau persepsi kegunaan yang dimana sistem (e-Filing) dikenalkan ke para wajib pajak pasti karena sistem memiliki manfaat untuk wajib pajak, yaitu untuk memudahkan wajib pajak dalam pelaporan pajak mereka. Persepsi kebermanfaatan ini muncul ketika eFiling telah memiliki kesiapan yang baik sehingga dapan membuat wajib pajak menilai 
bahwa e-Filing memiliki kesiapan yang dapat memberikan mereka manfaat yang lebih dari pada sistem manual (lama), sehingga persepsi ini akan mendorong keinginan wajib pajak untuk mau menggunakan e-Filing sebagai sarana pelaporan pajak.

Faktor Perceived Ease of Use juga digunakan untuk mendasari variabel kompleksitas, yang mana wajib pajak akan berminat menggunakan e-filing apabila kompleksitas dalam tata cara menggunakannya sangat rendah. Kompleksitas berkaitan dengan e-filing ini nantinya akan membentuk persepsi wajib pajak akan kemudahan dalam menggunakan. Wajib pajak akan menilai e-filing memiliki kemudahan untuk digunakan apabila melaporkan pajak melalui e-filing tidak memiliki kompleksitas. Setelah persepsi kemudahan penggunaan terbentuk yang dilihat dari kompleksitasnya, maka persepsi itu yang akan berdampak pada minat wajib pajak untuk menggunakan e-filing dalam melaporkan pajaknya.

\section{e-Filing}

e-Filing adalah suatu cara penyampaian Surat Pemberitahuan (SPT) secara elektronik yang dilakukan secara online dan real time melalui internet pada website Direktorat Jenderal Pajak (http://www.pajak.go.id) atau Penyedia Jasa Aplikasi Perpajakan (PJAP).

Bagi wajib pajak yang hendak menyampaikan laporan SPT Tahunan PPh Orang Pribadi (1770, 1770S, 1770SS) maupun SPT Tahunan PPh Badan (1771) dapat mengisi dan menyampaikan laporan SPT-nya pada aplikasi e-Filing di DJP Online (www.djponline.pajak.go.id).

\section{Pengetahuan Perpajakan}

Pengetahuan perpajakan bisa didapatkan wajib pajak melalui seminar atau penyuluhan perpajakan yang kemudian dapat memberikan dampak terhadap kesadaran wajib pajak untuk membayar pajak. Pengetahuan mengenai perpajakan sangat penting bagi wajib pajak agar mereka dapat melakukan proses administrasi pajak dengan baik dan benar.

Penelitian yang dilakukan oleh Rahayu (2016) menyatakan adanya pengaruh pengetahuan terhadap minat perilaku wajib pajak untuk menggunakan e-filing. Hipotesis yang diajukan adalah:

$H_{1}$ Pengetahuan berpengaruh terhadap minat perilaku wajib pajak orang pribadi dalam menggunakan e-Filing.

\section{Persepsi Kegunaan}

Persepsi kegunaan diartikan sebagai ukuran dimana ketika individu menggunakan teknologi tertentu akan memberikan wajib pajak suatu manfaat yang tidak didapatkan ketika tidak menggunakan teknologi tersebut. Persepsi kegunaan suatu pemikiran tertentu yang meyakini suatu individu bahwa penggunaan suatu teknologi yang baru akan meningkatkan kinerja individu tersebut (Desmayanti 2012).

Penelitian yang dilakukan oleh Rahayu (2016), Mujiyati, et al (2016), Ermawati dan Kuncoro (2016), Wibosono dan Toly (2014) menyatakan bahwa persepsi kegunaan memiliki pengaruh terhadap minat perilaku wajib pajak untuk menggunakan e-filing. Hipotesis yang diajukan adalah:

$\mathrm{H}_{2} \quad$ Persepsi kegunaan berpengaruh terhadap minat perilaku wajib pajak orang pribadi dalam menggunakan e-Filing.

\section{Persepsi Kemudahan}

Persepsi mengenai kemudahan dalam menggunakan suatu teknologi dapat diartikan menjadi tolak ukur dari kepercayaan individu bahwa teknologi mudah digunakan. Sistem teknologi yang berkuailitas dapat memberikan kepuasaan bagi pengguna karena memiliki kemudahan yang tidak didapat dari sistem sebelumnya. Kemudahan yang diberikan dapat berupa kemudahan dalam melakukan pekerjaan 
atau tugas yang dilakukan dengan menggunakan sistem tersebut.

Penelitian yang dilakukan oleh Rahayu (2016), Mujiyati, et al (2016), Utami (2017), Wibosono dan Toly (2014) menyatakan bahwa persepsi kemudahan memiliki pengaruh terhadap minat perilaku wajib pajak untuk menggunakan e-filing. Hipotesis yang diajukan adalah:

$\mathrm{H}_{3}$ Persepsi kemudahan berpengaruh terhadap minat perilaku wajib pajak orang pribadi dalam menggunakan e-Filing.

\section{Keamanan dan Kerahasiaan}

Keamanan memiliki arti ketika individu menggunakan sistem teknologi tersebut, tingkat resiko akan hilangnya informasi data pribadi dan resiko pencurian terhadap data tersebut sangat kecil. Sedangkan kerahasiaan dapat diartikan setiap informasi yang berkaitan terhadap pengguna tidak dapat diakses atau dilihat oleh siapapun (Sugihanti, 2011).

Penelitian yang dilakukan oleh Rahayu (2016), Mujiyati et al (2016), Wibisono dan Toly (2014) menyatakan bahwa keamanan dan kerahasiaan memiliki pengaruh terhadap minat perilaku wajib pajak untuk menggunakan e-filing . Hipotesis yang diajukan adalah :

$\mathrm{H}_{4} \quad$ Keamanan dan kerahasiaan berpengaruh terhadap minat perilaku wajib pajak orang pribadi dalam menggunakan e-Filing.

\section{Pengalaman}

Pengalaman dapat berarti sebagai bentuk pengetahuan yang diperoleh karena pengguna telah menggunakan suatu teknologi secara berulang-ulang. Pengalaman dapat mempengaruhi individu dalam menentukan pilihan dan menanggapi hal yang baru. Ketika pengguna menggunakan suatu teknologi yang baru, pengguna akan dipermudah karena sebelumnya pengguna sudah pernah menggunakan suatu teknologi.

Penelitian yang dilakukan oleh Mujiyati et al (2016) menyatakan bahwa pengalaman memiliki pengaruhi terhadap minat perilaku wajib pajak untuk menggunakan e-filing sedangkan penelitian yang dilakukan Rahayu (2016) bertolak belakang. Hipotesis yang diajukan adalah:

$\mathrm{H}_{5}$ Pengalaman berpengaruh terhadap minat perilaku wajib pajak orang pribadi dalam menggunakan e-Filing.

\section{Kesiapan Teknologi Informasi}

Terdapat dua faktor yang dapat mempengaruhi siap atau tidaknya teknologi informasi. Kedua faktor itu adalaah software dan hardware. Kedua faktor ini harus terpenuhi agar kegiatan yang berkaitan dengan kedua faktor tersebut berjalan dengan baik. Kesiapan teknologi bisa juga dilihat dari kemampuan pengguna untuk menggunakan teknologi. Apabila pengguna tidak mampu untuk mempersiapkan sarana yang berkaitan dengan teknologi informasi maka teknologi tersebut tidak dapat berjalan dengan baik.

Penelitian yang dilakukan oleh Utami (2016) menyatakan bahwa kesiapan teknologi informasi memiliki pengaruhi terhadap minat perilaku wajib pajak untuk menggunakan e-filing. Hipotesis yang diajukan adalah:

$\mathrm{H}_{6} \quad$ Kesiapan teknologi informasi berpengaruh terhadap minat perilaku wajib pajak orang pribadi dalam menggunakan e-Filing.

\section{Kompleksitas}

Kompleksitas terjadi bila pengguna tidak mengetahui suatu teknologi yang ingin ia gunakan dan tidak terbiasa dengan teknologi yang baru. Kompleksitas juga akan muncul apabila pengguna tidak mempelajari dengan baik teknologi yang ingin digunakan. Penelitian yang dilakukan oleh Ermawati dan Kuncoro (2016) menyatakan kompleksitas memiliki pengaruh terhadap minat perilaku wajib pajak untuk menggunakan e-filing. Hipotesis yang diajukan adalah:

$\mathrm{H}_{7}$ Kompleksitas berpengaruh terhadap minat perilaku wajib pajak orang pribadi dalam menggunakan e-Filing. 


\section{METODE PENELITIAN}

Data dalam penelitian ini diperoleh dengan cara menyebarkan kuesioner kepada setiap wajib pajak orang pribadi yang telah melaporkan Surat Pemberitahuan Pajaknya (SPT) dengan menggunakan sistem e-filing. Penyebaran kuesioner ini dimulai pada tanggal 30 Oktober 2018, yaitu dengan cara menyerahkan langsung kepada wajib pajak orang pribadi secara accidental, selain itu peneliti juga menggunakan kuesioner online dengan google form sebagai sarana lain dalam menyebarkan kuesioner kepada wajib pajak.

Metode analisis yang digunakan dalam penelitian ini adalah meliputi statistik deskriptif, Uji asumsi klasik dalam penelitian ini meliputi uji validitas dan reabilitas, multikolinearitas, heteroskedastisitas dan autokorelasi. Analisis data menggunakan analisis regresi linier berganda Selanjutnya dilakukan uji hipotesis yaitu uji F dan Uji t.

Minat perilaku wajib pajak dalam menggunakan e-Filing merupakan ukuran dari minat seseorang untuk menunjukkan suatu perilaku terhadap adanya sistem pelaporan pajak yang berbasis online (e-Filing). Jenis pertanyaan yang diajukan dalam penelitian terkait variabel minat perilaku wajib pajak dalam menggunakan e-Filing antara lain:

1. Saya akan selalu mencoba menggunakan eFiling setiap kali melaporkan pajak.

2. Saya berminat untuk menggunakan e-Filing untuk melaporkan SPT.

3. Saya merencanakan untuk menggunakan eFiling di masa depan.

4. Saya berkehendak untuk melanjutkan menggunakan e-Filing di masa depan.

5. Saya mengharapkan penggunaan e-Filing akan terus berlanjut di masa datang.

Pengetahuan adalah proses dimana wajib pajak mengetahui tata cara perpajakan. Pengetahuan mengenai tata cara perpajakan yang dimiliki oleh wajib pajak kemudian wajib pajak mengaplikasikannya untuk membayar pajak. Untuk melakukan pembayaran pajak, wajib pajak perlu mengetahui berbagai peraturan perpajakan agar wajib pajak dapat melakukan pembayaran pajak dengan baik dan benar. Jenis pertanyaan yang diajukan dalam penelitian terkait variabel pengetahuan antara lain:

1. Saya mengetahui e-Filing sebagai sarana pelaporan pajak secara online dan realtime.

2. Saya memahami e-Filing sebagai sarana pelaporan pajak secara online dan realtime.

3. Pengetahuan e-Filing saya peroleh dari sosialisasi yang diadakan oleh Kantor Pajak Pratama.

4. Saya mengetahui e-Filing dari seminar yang diadakan oleh Kantor Pajak Pratama.

5. e-Filing dapat di akses melalui media online.

6. e-Filing dapat di akses melalui internet.

Variabel Persepsi kegunaan didefinisikan bagaimana suatu individu memahami kegunaan atau manfaat dari pemakaian sistem teknologi informasi. Jika individu memahami bahwa e-Filing dapat menguntungkan mereka maka secara langsung mereka akan menggunakan sistem e-Filing tersebut. Namun sebaliknya jika seorang individu merasa kurang mempercayai atau tidak mengetahui dengan baik manfaat dari sistem eFiling tersebut maka akan timbul keraguan dalam diri wajib pajak untuk menggunakannya dalam melaporkan pajak. Jenis pertanyaan yang diajukan dalam penelitian mengenai variabel persepsi kegunaan antara lain:.

1. Penggunaan e-Filing dapat mempercepat pekerjaan saya.

2. Penggunaan e-Filing dapat meningkatkan performa pelaporan pajak saya.

3. Penggunaan e-Filing dapat meningkatkan efektivitas pelaporan pajak saya.

4. Penggunaan e-Filing dapat memudahkan pekerjaan saya tanpa perlu datang ke KPP.

5. Penggunaan e-Filing dapat meningkatkan kinerja saya. 
6. Secara keselurahan penggunaan e-Filing sangat bermanfaat bagi saya.

Variabel Persepsi kemudahan didefinisikan bagaimana suatu individu dapat menginterpretasikan bahwa mempelajari dan menggunakan sistem e-Filing tersebut merupakan hal yang mudah.Jenis pertanyaan yang diajukan dalam penelitian mengenai variabel persepsi kemudahan antara lain:

1. Saya merasa bahwa layanan e-Filing mudah.

2. Menggunakan e-Filing adalah mudah bagi saya.

3. Melaporkan pajak menggunakan e-Filing lebih mudah bagi saya.

4. Saya mudah beradaptasi dengan e-Filing.

5. e-Filing sangat fleksibel bagi pengguna dalam memanfaatkan layanan pelaporan perpajakan.

6. Secara keseluruhan e-Filing adalah mudah bagi saya.

Keamanan berarti ketika pengguna dalam hal ini wajib pajak menggunakan sistem teknologi informasi tersebut, resiko hilangnya data pribadi atau informasi dan resiko pencurian terhadap data mereka sangat kecil (Sugihanti, 2010). Kerahasiaan berarti segala sesuatu yang berkaitan dengan informasi pribadi pengguna atau wajib pajak terjamin kerahasiaannya, tidak ada orang lain yang dapat mengakses dan mengetahuinya. Isu keamanan dan kerahasiaan merupakan isu yang sangat diperhatikan oleh para pengguna ketika menggunakan sebuah sistem informasi. Jenis pertanyaan yang diajukan dalam penelitian mengenai variabel keamanan dan kerahasiaan, antara lain:

1. e-Filing dapat menjaga kerahasiaan data.

2. Tidak khawatir dengan keamanan sistem eFiling dalam menjaga data pengguna.

3. Pemanfaatan layanan laporan pajak dengan menggunakan e-Filing dapat memberikan tingkat jaminan keamanan dan kerahasiaan yang tinggi.

4. Penggunaan e-Filing secara keseluruhan merasa lebih aman dan rahasia.

Pengalaman ada suatu kejadian yang pernah dialami sebelumnya terutama pengalaman dalam menggunakan teknologi sebelumnya. Wajib pajak yang memiliki pengalaman dalam menggunakan teknologi akan memudahkannya dalam menggunakan eFiling sehingga dapat mempengaruhi minat perilaku wajib pajak untuk menggunakan eFiling. Jenis pertanyaan yang diajukan dalam penelitian mengenai pengalaman, antara lain:

1. Saya memiliki banyak pengalaman dalam menggunakan e-Filing.

2. Saya bertahun - tahun menggunakan eFiling.

Kesiapan teknologi informasi berarti bahwa individu atau wajib pajak dalam hal ini harus siap menerima perkembangan teknologi yang ada terkhusus dengan munculnya sistem e-Filing. Jenis pertanyaan yang diajukan dalam penelitian mengenai kesiapan teknologi informasi, antara lain:

1. Tersedianya koneksi internet yang baik

2. Tersedianya sarana dan fasilitas software dan hardware yang baik

3. SDM yang paham akan teknologi

Pengukuran variabel-variabel di atas diukur dengan menggunakan skala likert 5 poin (5-point likert scale) dimulai dari poin 1 sangat tidak setuju (STS), poin 2 tidak setuju (TS), poin 3 ragu-ragu (R), poin 4 setuju $(S)$, poin 5 sangat setuju (SS).

Adapun jumlah kuesioner yang disebar dapat dilihat pada tabel berikut: 
Tabel 1 Penyebaran Kuesioner

\begin{tabular}{lcc}
\hline Keterangan & Jumlah & Persentase \\
\hline Kuesioner yang disebar & 137 & $100 \%$ \\
Kuesioner yang tidak kembali & 0 & $0 \%$ \\
Kuesioner yang tidak dapat diolah & 27 & $16,03 \%$ \\
Kuesioner yang dapat diolah & 110 & $83,97 \%$ \\
\hline
\end{tabular}

Sumber : Data yang diolah

Jumlah kuesioner yang telah disebar oleh peneliti adalah sebanyak 137 kuesioner. Jumlh kuesioner yang tidak dapat kembali adalah tidak ada atau nol. Jumlah kuesioner yng tidak dapat diolah adalah berjumlah 27 kuesioner atau
$16,03 \%$. Kuesioner ini tidak dapat diolah karena jawaban yang diberikan oleh responden tidak lengkap. Kuesioner yang dapat diolah untuk penelitian adalah berjumlah 110 kuesioner atau $83,97 \%$.

Tabel 2 Karakterisik Responden

\begin{tabular}{|c|c|c|c|}
\hline \multicolumn{2}{|c|}{ Keterangan } & \multirow{2}{*}{$\begin{array}{c}\text { Jumlah } \\
64\end{array}$} & \multirow{3}{*}{$\begin{array}{c}\text { Persentase } \\
58,18 \% \\
41,82 \% \\
\end{array}$} \\
\hline & Laki - Laki & & \\
\hline Jenis Kelamin & Perempuan & 46 & \\
\hline \multirow{5}{*}{ Umur Responden } & $18-25$ & 51 & $46,36 \%$ \\
\hline & $26-35$ & 50 & $45,46 \%$ \\
\hline & $36-45$ & 6 & $5,46 \%$ \\
\hline & $46-55$ & 2 & $1,82 \%$ \\
\hline & $>55$ & 1 & $0,9 \%$ \\
\hline \multirow{5}{*}{ Pekerjaan } & PNS & 0 & $0 \%$ \\
\hline & Pegawai Swasta & 99 & $90 \%$ \\
\hline & Wirausaha & 9 & $8,18 \%$ \\
\hline & Pekerjaan Bebas & 2 & $1,82 \%$ \\
\hline & Lainnya & 0 & $0 \%$ \\
\hline \multirow{5}{*}{$\begin{array}{l}\text { Pendidikan } \\
\text { Terakhir }\end{array}$} & SMP/Sederajat & 1 & $0,9 \%$ \\
\hline & SMA/Sederajat & 0 & $0 \%$ \\
\hline & Diploma & 5 & $4,55 \%$ \\
\hline & Sarjana & 104 & $94,55 \%$ \\
\hline & Pascasarjana & 0 & $0 \%$ \\
\hline \multirow{2}{*}{$\begin{array}{l}\text { Menggunakan e- } \\
\text { filing atau tidak }\end{array}$} & $\mathrm{Ya}$ & 110 & $100 \%$ \\
\hline & Tidak & 0 & $0 \%$ \\
\hline
\end{tabular}




\section{HASIL PENELITIAN}

Tabel 3 Statistik Deskriptif

\begin{tabular}{lccccc}
\hline \multicolumn{1}{c}{ Variabel } & N & Min. & Max. & Mean & Stand. Deviation \\
\hline Pengetahuan & 110 & 20 & 28 & 22,95 & 1,96219 \\
Persepsi Kegunaan & 110 & 18 & 30 & 25,48 & 2,97307 \\
Persepsi Kemudahan & 110 & 17 & 27 & 23,31 & 2,17890 \\
Keamanan dan Kerahasiaan & 110 & 12 & 20 & 16,11 & 1,94108 \\
Pengalaman & 110 & 3 & 8 & 5,18 & 1,41539 \\
Kesiapan Teknologi Informasi & 110 & 10 & 15 & 13,46 & 1,48804 \\
Kompleksitas & 110 & 15 & 25 & 20,80 & 2,00367 \\
Minat Perilaku & 110 & 17 & 25 & 22,94 & 2,32370 \\
\hline
\end{tabular}

Sumber : Hasil pengolahan data SPSS

Berdasarkan hasil pada tabel 3, nilai rata - rata variabel pengetahuan sebesar 22,95 yang jika dibagi dengan jumlah pertanyaan yang ada yaitu sebanyak 6 pertanyaan maka akan menghasilkan nilai 3,825 yang artinya responden cenderung menjawab pertanyaan dengan memberikan penilaian ragu - ragu. Nilai minimum 20 dan nilai maksimum 28. Nilai Standar Deviasi sebesar 1,96219.

Nilai rata - rata variabel persepsi kegunaan sebesar 25,48 yang jika dibagi dengan jumlah pertanyaan yang ada yaitu sebanyak 6 pertanyaan maka akan menghasilkan nilai 4,25 yang artinya responden cenderung menjawab pertanyaan dengan memberikan penilaian setuju. Nilai minimum 18 dan nilai maksimum 30. Nilai Standar Deviasi sebesar 2,97307.

Nilai rata - rata variabel persepsi kemudahan sebesar 23,31 yang jika dibagi dengan jumlah pertanyaan yang ada yaitu sebanyak 6 pertanyaan maka akan menghasilkan nilai 3,885 yang artinya responden cenderung menjawab pertanyaan dengan memberikan penilaian ragu - ragu. Nilai minimum 17 dan nilai maksimum 27. Nilai Standar Deviasi sebesar 2,17890.

Nilai rata - rata variabel keamanan dan kerahasiaan sebesar 16,11 yang jika dibagi dengan jumlah pertanaan yang ada yaitu sebanyak 4 pertanyaan maka akan menghasilkan nilai 4,0275 yang artinya responden cenderung menjawab pertanyaan dengan memberikan penilaian setuju. Nilai minimum 12 dan nilai maksimum 20. Nilai Standar Deviasi sebesar 1,94108.

Nilai rata - rata variabel pengalaman sebesar 5,182 yang jika dibagi dengan jumlah pertanyaan yang ada yaitu sebanyak 2 pertanyaan maka akan menghasilkan nilai 2,591 yang artinya responden cenderung menjawab pertanyaan dengan memberikan penilaian tidak setuju. Nilai minimum 3 dan nilai maksimum 8 . Nilai Standar Deviasi sebesar 1,41539.

Nilai rata - rata variabel kesiapan teknologi informasi sebesar 13,46 yang jika dibagi dengan jumlah pertanyaan yang ada yaitu sebanyak 3 pertanyaan maka akan menghasilkan nilai 4,49 yang artinya responden cenderung menjawab pertanyaan dengan memberikan penilaian setuju. Nilai minimum 10 dan nilai maksimum 15. Nilai Standar Deviasi 1,48804 .

Nilai rata - rata variabel kompleksitas sebesar 20,8 yang jika dibagi dengan jumlah pertanyaan yang ada yaitu sebanyak 5 pertanyaan maka akan menghasilkan nilai 4,16 yang artinya responden cenderung menjawab pertanyaan dengan memberikan penilaian setuju. Nilai minimum 15 dan nilai maksimum 25. Nilai Standar Deviasi 2,00367.

Untuk variabel minat perilaku wajib pajak memberikan nilai rata - rata sebesar 22.94 yang jika dibagi dengan banyaknya jumlah 
pertanyaan yang ada yaitu 5 pertanyaan, maka akan menghasilkan nilai 4,588 yang artinya responden cenderung menjawab pertanyaan dengan memberikan penilaian setuju. Nilai minimum 17 dan nilai maksimum 25. Nilai Standar Deviasi 2,32370.

Tabel 4 Hasil Uji Reliabilitas

\begin{tabular}{lc}
\hline Variabel & Nilai Cronbach's Alpha \\
\hline Pengetahuan & 0,710 \\
Persepsi Kegunaan & 0,915 \\
Persepsi Kemudahan & 0,938 \\
Keamanan dan Kerahasiaan & 0,912 \\
Pengalaman & 0,964 \\
Kesiapan Teknologi Informasi & 0,871 \\
Kompleksitas & 0,860 \\
Minat Perilaku Wajib Pajak & 0,911 \\
\hline Sumber : Hasil Pengolahan Data dengan SPSS &
\end{tabular}

Dari data diatas dapat disimpulkan bahwa nilai Cronbach's Alpha dari setiap instrumen lebih besar dari 0,7 maka semua variabel independen dan dependen dapat dinyatakan reliabel.

Hasil pengujian validitas menunjukkan bahwa nilai sig. 2 (tailed) dari setiap butir variabel pengetahuan, persepsi kegunaan, persepsi kemudahan, keamanan dan kerahasiaan, pengalaman, kesiapan teknologi informasi, kompleksitas, dan minat perilaku wajib pajak sebesar 0,000 $<0,05$ maka hal ini menunjukkan bahwa setiap butir pernyataan pada setiap variabel yang ada didalam kuesioner ini dinyatakan valid.

Tabel 5 Hasil Uji Normalitas Data

\begin{tabular}{lc}
\hline & Unstandardized Residual \\
\hline $\mathrm{N}$ & 110 \\
Kolmogorov-Smirnov & 0,736 \\
Asymp.Sig. (2-tailed) & 0,651 \\
\hline
\end{tabular}

Sumber : Hasil Pengolahan Data dengan SPSS

Berdasarkan hasil pengujian One-Sample Kolmogorov-Smirnov diketahui bahwa nilai asymptotic significant adalah 0,651 lebih besar dari 0,05 sehingga dapat dikatakan bahwa data residual berdistribusi normal dan model regresi memenuhi asumsi normalitas

Tabel 6 Hasil Analisis Koefisien Korelasi dan Koefisien Determinasi

\begin{tabular}{cccc}
\hline $\mathbf{R}$ & $\mathbf{R}$ Square & Adj R Square & Std. Error of the Estimate \\
\hline 0,782 & 0,612 & 0,585 & 1,49702
\end{tabular}

Sumber : Hasil Pengolahan Data dengan SPSS

Berdasarkan pada tabel 6 dapat dilihat bahwa nilai koefisien korelasi ( $R$ ) adalah sebesar 0,782 yang artinya secara statistik hubungan antara variabel dependen minat perilaku wajib pajak dan variabel independen pengetahuan, persepsi kegunaan, persepsi kemudahan, keamanan dan kerahasiaan, pengalaman, kesiapan teknologi informasi, dan kompleksitas adalah kuat karena terletak diantara 0,60-0,799. 
Berdasarkan pada tabel 6 dapat dilihat bahwa nilai koefisien determinasi (Adj $R$ square) adalah sebesar 0,585 yang artinya secara statistik besarnya variasi variabel dependen minat perilaku wajib pajak yang dapat dijelaskan oleh variasi variabel independen adalah sebesar $58,5 \%$ sedangkan sisanya sebesar 41,5\% dijelaskan oleh variasi variabel lain yang tidak dimasukkan ke dalam model regresi.

Tabel 7 Hasil Uji F (ANOVA)

\begin{tabular}{lll}
\hline Model & $\mathrm{F}$ & Sig. \\
\hline Regression & 22,946 & $0,000^{\mathrm{a}}$ \\
\hline Sumber : Hasil Pengolahan Data dengan SPSS &
\end{tabular}

Berdasarkan tabel 7 dapat dilihat bahwa nilai $\mathrm{F}$ sebesar 22,946 dengan signifikansi 0,000. Hal ini menandakan model regresi fit dan layak digunakan dalam penelitian karena memiliki nilai signifikansi yang lebih kecil dari nilai alpha 0,05.

Tabel 8 Hasil Uji t

\begin{tabular}{lccc}
\hline Variabel & B & t & Sig. \\
\hline (Constant) & $-0,951$ & $-0,406$ & 0,686 \\
Pengetahuan $\left(X_{1}\right)$ & 0,180 & 2,057 & 0,042 \\
Persepsi Kegunaan $\left(X_{2}\right)$ & 0,202 & 3,007 & 0,003 \\
Persepsi Kemudahan $\left(X_{3}\right)$ & 0,427 & 4,498 & 0,000 \\
Keamanan dan Kerahasiaan $\left(X_{4}\right)$ & 0,184 & 1,985 & 0,050 \\
Pengalaman $\left(X_{5}\right)$ & 0,226 & 1,989 & 0,049 \\
Kesiapan Teknologi Informasi $\left(X_{6}\right)$ & 0,077 & 0,619 & 0,537 \\
Kompleksitas $\left(X_{7}\right)$ & $-0,024$ & $-0,253$ & 0,800 \\
\hline
\end{tabular}

Sumber : Hasil Pengolahan Data dengan SPSS

Berdasarkan Tabel 8, dapat diketahui nilai konstanta dan koefisien regresi untuk masing-masing variabel independen yang akan digunakan untuk menyusun persamaan regresi sebagaimana disajikan berikut ini:

$$
\begin{aligned}
Y= & a+b_{1} X_{1}+b_{2} X_{2}+b_{3} X_{3}+b_{4} X_{4}+ \\
& b_{5} X_{5}+b_{6} X_{6}+\varepsilon
\end{aligned}
$$

$Y=-0,951+0,180 X_{1}+0,202 X_{2}+0,427 X_{3}+$ $0,184 X_{4}+0,226 X_{5}+0,077 X_{6}-0,024 X_{7}+\varepsilon$

Hasil olah statistik untuk variabel pengetahuan (X1) memiliki nilai signifikansi 0,042 dan memiliki nilai koefisien regresi 0,180. Nilai signifikansi yang dimiliki oleh variabel pengetahuan < nilai alpha 0,05 dan nilai koefisien regresi bersifat positif, maka Ha1 diterima atau dapat disimpulkan variabel pengetahuan berpengaruh secara positif terhadap minat perilaku wajib pajak orang pribadi dalam menggunakan e-filing. Hasil penelitian konsisten dengan hasil penelitian Rahayu (2016) yang membuktikan bahwa pengetahuan berpengaruh terhadap minat perilaku wajib pajak dalam menggunakan efiling. Pada saat wajib pajak memahami dan mengetahui mengenai perpajakan maka akan memberikan kesadaran terhadap wajib pajak untuk membayar pajak dan dengan adanya pengetahuan terhadap perpajakan maka wajib pajak juga akan mengetahui sistem e-filing yang dapat digunakan untuk melaporkan Surat Pemberitahuan Tahunan (SPT) secara online atau dengan kata lain tanpa perlu datang ke KPP.

Hasil olah statistik untuk variabel persepsi kegunaan (X2) memiliki nilai signifikansi 0,003 dan memiliki nilai koefisien regresi 0,202 . Nilai signifikansi dari variabel 
persepsi kegunaan < nilai alpha 0,05 dan nilai koefisien regresi bersifat positif, maka $\mathrm{Ha} 2$ diterima atau dapat disimpulkan bahwa variabel persepsi kegunaan berpengaruh terhadap minat perilaku wajib pajak orang pribadi dalam menggunakan e-filing. Hasil konsisten dengan Rahayu (2016) yang membuktikan persepsi kegunaan memiliki pengaruh secara positif terhadap minat perilaku wajib pajak dalam menggunakan e-filing. Persepsi kegunaan sendiri dapat diartikan sebagai derajat dari keyakinan individu apabila ia memakai sistem tertentu akan meningkatkan kinerja. Dalam hal ini wajib pajak mempersepsikan e-filing, apabila wajib pajak meyakini bahwa e-filing meningkatkan kinerja mereka dalam melaporkan pajak karena penggunaan e-filing dapat dilakukan kapan saja, lebih cepat dan praktis, maka wajib pajak akan selalu menggunakan e-filing.

Hasil olah statistik untuk variabel persepsi kemudahan (X3) didapatkan nilai signifikansi 0,000 dan memiliki nilai koefisien regresi 0,427 . Nilai signifikansi yang dimiliki oleh variabel persepsi kemudahan < nilai alpha 0,05 dan nilai koefisien regresi bersifat positif, maka Ha3 diterima atau dapat disimpulkan bahwa variabel persepsi kemudahan berpengaruh secara positif terhadap minat perilaku wajib pajak orang pribadi dalam menggunakan efiling. Hasil penelitian konsisten dengan hasil penelitian Rahayu (2016), Mujiyati et al (2016) dan Utami (2017) yang membuktikan persepsi kemudahan memiliki pengaruh terhadap minat perilaku wajib pajak dalam menggunakan efiling. Kemudahan dapat mengacu pada cara menggunakan sistem e-filing atau perbedaan tingkat kemudahan antara sistem yang lama yaitu, wajib pajak harus datang ke KPP untuk melaporkan SPT dengan sistem yang baru dimana wajib pajak tidak perlu datang ke KPP untuk melaporkan SPT. Semakin tinggi wajib pajak mempersepsikan bahwa e-filing memberikan kemudahan dalam pelaporan SPT maka wajib pajak akan cenderung selalu menggunakan e-filing.

Hasil olah statistik untuk variabel keamanan dan kerahasiaan (X4) memiliki nilai signifikansi sebesar 0,050 dan memiliki nilai koefisien regresi sebesar 0,184 . Nilai signifikansi yang dimiliki oleh variabel keamanan dan kerahasiaan sama dengan alpha 0,05 dan nilai koefisien bersifat negatif maka, Ha4 diterima atau dapat simpulkan variabel keamanan dan kerahasiaan berpengaruh secara positif terhadap minat perilaku wajib pajak orang pribadi dalam menggunakan e-filing. Hasil penelitian konsisten dengan penelitian Mujiyati et al (2016), dan Wibisono (2014) yang membuktikan bahwa keamanan dan kerahasiaan berpengaruh terhadap minat wajib pajak dalam menggunakan e-filing. Dalam hal ini wajib pajak meyakini bahwa sistem e-filing aman dan dapat menjaga data mereka. Semakin aman dan terjaminnya data - data wajib pajak yang berada pada database sistem e-filing maka wajib pajak akan selalu menggunakan teknologi e-filing dalam melaporkan SPT.

Hasil olah statistik untuk variabel pengalaman (X5) memiliki nilai signifikansi sebesar 0,049 dan memiliki nilai koefisien regresi sebesar 0,266. Nilai signifikansi 0,049< nilai alpha 0,05 dan nilai koefisien bersifat positif maka, Ha5 diterima atau dapat disimpulkan variabel keamanan dan kerahasiaan berpengaruh secara positif terhadap minat perilaku wajib pajak orang pribadi dalam menggunakan e-filing. Kesimpulan ini konsisten dengan hasil penelitian Mujiyati et al (2016) yang membuktikan bahwa pengalaman berpengaruh terhadap minat wajib pajak dalam menggunakan e-filing.

Hasil olah statistik untuk variabel kesiapan teknologi informasi (X6) diperoleh nilai signifikansi 0,537 dan nilai koefisien 0,077 . Nilai signifikansi yang dimiliki oleh variabel kesiapan teknologi informasi lebih besar dari batas signifikansi 0,05 dan nilai koefisien bersifat positif maka, Ha6 tidak diterima atau dapat 
disimpulkan bahwa kesiapan teknologi informasi tidak berpengaruh terhadap minat wajib pajak orang pribadi dalam menggunakan e-filing. Hasil ini tidak konsisten dengan penelitian Utami (2017) yang membuktikan bahwa kesiapan teknologi informasi berpengaruh secara positif terhadap minat perilaku wajib pajak dalam menggunakan e-filing.

Hasil olah statistik untuk variabel kompleksitas (X7) diperoleh nilai signifikansi 0,800 dan nilai koefisien regresi sebesar $-0,024$. Nilai signifikansi yang dimiliki oleh variabel kompleksitas lebih besar dari batas signifikansi 0,05 dan nilai koefesien bersifat negatif maka, Ha7 tidak diterima atau dapat disimpulkan bahwa kompleksitas tidak berpengaruh terhadap minat wajib pajak orang pribadi dalam menggunakan e-filing. Hasil penelitian ini bertolak belakang dengan hasil penelitian Ermawati (2016) yang membuktikan kompleksitas berpengaruh terhadap minat perilaku wajib pajak dalam menggunakan efiling.

\section{PENUTUP}

Berdasarkan dari hasil analisa yang telah dilakukan, maka dapat disimpulkan:

1. Pengetahuan berpengaruh secara positif terhadap minat perilaku wajib pajak dalam menggunakan e-filing. Hasil ini konsisten dengan penelitian yang dilakukan oleh Rahayu (2016).

2. Persepsi kegunaan berpengaruh secara positif terhadap minat perilaku wajib pajak dalam menggunakan e-filing. Hasil ini konsisten dengan penelitian Rahayu (2016), Mujiyati, et al (2016), Ermawati dan Kuncoro (2016), Wibisono dan Toly (2014).

3. Persepsi kemudahan berpengaruh secara positif terhadap minat perilaku wajib pajak dalam menggunakan e-filing. Hasil ini konsisten dengan penelitian yang dilakukan oleh Rahayu (2016), Mujiyati, et al (2016), Utami (2017), Wibisono dan Toly (2014).
4. Kerahasiaan dan keamanan berpengaruh secara positif terhadap minat perilaku wajib pajak dalam menggunakan e-filing. Hasil ini konsisten dengan penelitian yang dilakukan oleh Rahayu (2016), Mujiyati, et al (2016), Wibisono dan Toly (2014).

5. Pengalaman berpengaruh secara positif terhadap minat perilaku wajib pajak dalam menggunakan e-filing. Hasil ini konsisten dengan penelitian yang dilakukan oleh Mujiyati et al (2016) dan tidak konsisten dengan Rahayu (2016)

6. Kesiapan teknologi informasi tidak berpengaruh terhadap minat perilaku wajib pajak dalam menggunakan e-filing. Hasil ini tidak konsisten dengan penelitian yang dilakukan oleh Utami (2017)

7. Kompleksitas tidak berpengaruh terhadap minat perilaku wajib pajak dalam menggunakan e-filing. Hasil ini tidak konsisten dengan penelitian yang dilakukan oleh Ermawati dan Kuncoro (2016)

Penelitian ini memiliki keterbatasan keterbatasan dengan uraian sebagai berikut:

1. Penelitian ini hanya menggunakan sampel seratus sepuluh responden dikarenakan keterbatasan waktu dan biaya, maka peneliti tidak dapat meneliti lebih banyak responden.

2. Pengisian kuesioner tanpa pengawasan secara detil, sehingga jawaban yang diperoleh mungkin saja tidak menggambarkan keadaan yang sesungguhnya.

Atas dasar pembahasan diatas peneliti menyarankan beberapa rekomendasi yang diharapkan dapat berguna bagi peneliti selanjutnya yang ingin melakukan penelitian dengan topik yang serupa. Beberapa rekomendasi sebagai berikut :

1. Bagi Peneliti selanjutnya sebaiknya memperbesar jumlah data yang akan diolah dalam penelitian. Hal ini dimaksudkan untuk 
kesimpulan penelitian yang dihasilkan oleh peneliti selanjutnya menjadi lebih akurat.

2. Bagi peneliti selanjutnya diharapkan pengisian kuesioner terhadap responden lebih diperhatikan, seperti sedikit diskusi agar jawaban yang diperoleh lebih menggambarkan keadaan responden yang sebenarnya

\section{REFERENCES:}

Ajzen, Icek. 2005. Attitudes, Personality and Behavior, (2nd edition). Berkshire, UK: Open University PressMcGraw Hill Education

Davis, F.D., 1989. Perceived Usefulness, Perceived Ease of Use, and Acceptance of Information System Technology. MIS Quarterly. Vol. 13, No. 3, h. 319- 339

Davis, F.D., Richard Bagozzi dan Paul Warshaw. 1989. User Acceptance of Computer Technology: A Comparison of Two Theoritical Models. Management Science, Vol. 35, No. 8, pp. 982-1003

Desmayanti, Esy. 2012. Faktor-faktor yang Mempengaruhi Penggunaan Fasilitas e-filing oleh WP sebagai Sarana Penyampaian SPT Masa Secara Online dan Realtime (Studi Empiris di Kota Semarang). Skripsi. Semarang: Universitas Diponegoro.

Direktorat Jenderal Pajak. 2018. Direktori Layanan Perpajakan. Jakarta.

Ermawati, Nanik dan Amin Kuncoro. 2016. Faktor - Faktor yang Mempengaruhi Minat Perilaku Wajib Pajak Untuk Menggunakan E-Filing. Unisbank Semarang, 28 Juli 2016.

Lai, Ling Ming dan Kwai Fatt Choong. 2010. Motivators, Barriers and Concerns in Adoption of Electronic Filing System: Survey Evidence from Malaysian Professional Accountants. American Journal Of Applied Sciences, ISSN 1554-3641, Vol. 7, Iss. 4, pp. 562-567.

Laihad, Risal C.Y., 2012. Pengaruh Perilaku Wajib Pajak Terhadap Penggunaan e- Filling Wajib Pajak di Kota Manado. Jurnal EMBA. ISSN 2303-1174. Vol.1 No.3 September 2013.

Mujiyati, et al. 2016. Faktor - Faktor yang Mempengaruhi Penggunaan E-Filing Bagi Wajib Pajak Orang Pribadi (Studi Empiris pada Wajib Pajak di KPP Sukoharjo dan KPP Surakarta). Syariah Paper Accounting FEB UMS. ISSN 2460-0784. Universitas Muhammadiyah Surakarta.

Peraturan Direktorat Jenderal Pajak No.Per1/PJ/2014 Tentang Tata Cara Penyampaian Surat Pemberitahuan Tahunan Bagi Wajib Pajak Orang Pribadi Yang Menggunakan Formulir 1770s Atau 1770ss Secara EFiling Melalui Website Direktorat Jenderal Pajak.

Peraturan Direktorat Jenderal Pajak Nomor 35 Tahun 2013 Tentang Tata Cara Ekstensifikasi.

Peraturan Direktorat Jenderal Pajak Nomor 36 Tahun 2013 Tentang Perubahan Atas Peraturan Direktur Jenderal Pajak Nomor Per-47/Pj/2008 Tentang Tata Cara Penyampaian Surat Pemberitahuan Dan Penyampaian Pemberitahuan Perpanjangan Surat Pemberitahuan Tahunan Secara Elektronik (E-Filing) Melalui Perusahaan Penyedia Jasa Aplikasi (ASP).

Peraturan Direktorat Jenderal Pajak Nomor PER - 01/PJ/2017 Tentang Penyampaian Surat Pemberitahuan Elektronik.

Peraturan Direktur Jendral Pajak Nomor PER-26/PJ/2014 Tentang Sistem Pembayaran Pajak Secara Elektronik.

Peraturan Menteri Keuangan 182/PMK.03/2015 Tentang Tata Cara Pendaftaran Nomor Pokok Wajib Pajak, Pengukuhan Pengusaha Kena Pajak, Penghapusan Nomor Pokor Wajib Pajak, dan Pencabutan Pengukuhan Pengusaha Kena Pajak.

Rahayu, Anita. 2016. Faktor - Faktor yang Mempengaruhi Minat Perilaku Wajib Pajak Dalam Menggunakan EFiling Sebagai Sarana Pelaporan Pajak (Studi Empiris Wajib Pajak Orang Pribadi di Kediri). Jurnal Akuntansi dan Ekonomi Bisnis. ISSN 2548-5326. Vol.5, p. 20-33, April. 2016. Politeknik Kediri.

Sugihanti, Winna. 2011. Analisis Faktor-Faktor yang mempengaruhi Minat Perilaku Wajib Pajak Untuk Menggunakan E-Filling (Studi Empiris Pada Wajib Pajak Badan Kota Semarang). Skripsi. Universitas Diponegoro. Semarang

Undang-Undang Nomor 28 Tahun 2007 tentang Ketentuan Umum dan Tata Cara Perpajakan. 
Utami, Adisti P., 2017. Analisa Faktor - Faktor yang Mempengaruhi Penggunaan E-Filing Wajib Pajak Orang Pribadi (Studi pada Wajib Pajak Orang Pribadi yang Berdomisili di Kota Tangerang). Ultima Accounting. ISSN 2085-4595. Vol. 9, No. 2. Desember 2017. Universitas Multimedia Nusantara. 
